\title{
Study of the Corrosive Behavior of the AISI 1020 Steel in Acid Crude Oil by Microscopic Techniques (LM, AFM and SEM/EDX) and Raman Spectroscopy
}

\author{
Heloisa P. Dias, ${ }^{a}$ Eliane V. Barros, ${ }^{b}$ Cristina M. S. Sad, ${ }^{a}$ Enrique R. Yapuchura, ${ }^{c}$ \\ Alexandre O. Gomes, ${ }^{d}$ Robson Moura, ${ }^{d}$ Fernanda E. Pinto, ${ }^{a}$ Débora V. Domingos, ${ }^{a}$ \\ Glória M. F. V. Aquije, ${ }^{\text {be }}$ Valdemar Lacerda Jr. ${ }^{*, a}$ and Wanderson Romão ${ }^{*, a, e}$
}

\author{
${ }^{a}$ Laboratório de Petroleômica e Forense, Departamento de Química, \\ Universidade Federal do Espírito Santo (UFES), 29075-910 Vitória-ES, Brazil \\ ${ }^{b}$ Instituto Federal do Espírito Santo, 1729, 29056-255 Vitória-ES, Brazil \\ ${ }^{c}$ Laboratório de Materiais Carbonosos e Cerâmicos, Departamento de Física, \\ Universidade Federal do Espirito Santo (UFES), 29075-910 Vitória-ES, Brazil \\ ${ }^{d}$ PETROBRAS CENPES, Ilha do Fundão, 21941-915 Rio de Janeiro-RJ, Brazil \\ ${ }^{e}$ Instituto Federal do Espírito Santo, 29106-010 Vila Velha-ES, Brazil
}

\begin{abstract}
Microscopic techniques were combined to study the influence of corrosion rate on the morphologic behavior of AISI 1020 steel specimens submitted to thermal degradation of a typical acid crude oil (total acid number $(\mathrm{TAN})=2.1390 \mathrm{mg} \mathrm{KOH} \mathrm{g}^{-1}$ and total sulfur $(\mathrm{S})=0.7778 \mathrm{wt}$.\%). The techniques used were light microscopy (LM), scanning electron microscopy/energy dispersive spectroscopy (SEM/EDX), atomic force microscopy (AFM) as well as Raman spectroscopy. Assays were performed in six different degradation time $(\mathrm{t}=6,12,24,36,48$ and $72 \mathrm{~h})$ at $320{ }^{\circ} \mathrm{C}$. After the exposure of the specimens to petroleum, a reduction above $37 \%$ in the TAN after $\mathrm{t}=72 \mathrm{~h}$ was observed, with a maximum corrosion rate during the first periods of degradation ( $\mathrm{t}=6$ and $12 \mathrm{~h}$ ). Correlating the TAN and corrosion rate data with the microscopic data, the images of LM, AFM, and SEM/EDX showed that after $6 \mathrm{~h}$ of exposure to petroleum, a passivation film was formed on the surface of the steel. This film consisted of two layers, an external one, formed of FeS, and an internal one, composed of iron oxides and oxyhydroxides. However, after $48 \mathrm{~h}$ of thermal degradation, this morphology was altered to a single layer of FeS coating the steel surface.
\end{abstract}

Keywords: crude oil, corrosion rate, naphthenic acids, TAN, AFM, SEM/EDX

\section{Introduction}

The damages caused by the naphthenic corrosion were observed for the first time in $1920 .^{1-3}$ Since then, the search for solutions to overcome these problems has become a constant challenge for the petroleum industry. ${ }^{4}$ Although naphthenic acids (NAs) represent less than 3 wt.\% of this matrix, they are considered the main responsible for the corrosion during the refining step. ${ }^{5,6}$ NAs are organic compounds with saturated rings and one or more carboxylic groups, with the basic formula of $\mathrm{R}\left[\mathrm{CH}_{2}\right]_{n} \mathrm{COOH}$, where $\mathrm{R}$ is usually a cyclopentane or cyclohexane ring. The corrosion due to the NAs occurs when the petroleum or its derivatives have acidity

*e-mail: vljuniorqui@gmail.com; wandersonromao@gmail.com greater than $0.5 \mathrm{mg}$ of $\mathrm{KOH} \mathrm{g}{ }^{-1}$ and are subjected to high refining temperatures (between 200 and $400{ }^{\circ} \mathrm{C}$ ). The naphthenic acidity and the degree of corrosivity of the petroleum are usually evaluated by the total acid number (TAN) measurements, which corresponds to the amount of $\mathrm{KOH}$ (in $\mathrm{mg}$ ) required to neutralize $1 \mathrm{~g}$ of petroleum or its fraction. ${ }^{7,8}$ A corrosion mechanism is proposed by equations 1,2 and 3 , in which the iron naphthenate is one of the corrosion products, being soluble in the crude oil, and thus, cannot protect against a continue corrosive process (equation 1). The naphthenic corrosion can also be associated with the $\mathrm{H}_{2} \mathrm{~S}$ (equations 2 and 3), which is responsible for the reconstitution of naphthenic acids, due to its attack on the iron naphthenate, turning the process autocatalytic (equation 3). ${ }^{5}$ The $\mathrm{R}$ symbol denotes the naphthenic acid group (equations 1 and 3 ), and 
$\mathrm{Fe}(\mathrm{RCOO})_{2}$ (equation 1) is the corrosion product soluble in the middle of the petroleum. ${ }^{5,9,10}$

$$
\begin{aligned}
& \mathrm{Fe}+2 \mathrm{RCOOH} \rightarrow \mathrm{Fe}(\mathrm{RCOO})_{2}+\mathrm{H}_{2} \\
& \mathrm{Fe}+\mathrm{H}_{2} \mathrm{~S} \rightarrow \mathrm{FeS}+\mathrm{H}_{2} \\
& \mathrm{Fe}(\mathrm{RCOO})_{2}+\mathrm{H}_{2} \mathrm{~S} \rightarrow \mathrm{FeS}+2 \mathrm{RCOOH}
\end{aligned}
$$

The working temperature, the TAN, the total sulfur (S) content and the steel-type used in the refinery influences the naphthenic corrosion rate. ${ }^{10,11}$ Also, studies have shown that the structure and molecular weight of NAs also influence in the corrosion. ${ }^{3}$

Before the choice in large-scale of the metallic materials in the petroleum industry, it is important to perform the monitoring of the corrosion rate. This monitoring consists in the use of weight loss measurements and of techniques that allow evaluating and preventing the development of a corrosive process that will affect the integrity of equipment or installations as well as their operational reliability. ${ }^{12}$ The study of the corrosion rate provoked by the acidic crude oil and its derivatives is commonly carried out by monitoring in situ specimens during the petroleum production or in laboratory analyzes.

In industry, the main procedure adopted to evaluate the corrosion rate is standardized by the ASTM G31-72, ${ }^{13}$ which describes the procedures and the factors that influence in the corrosion tests in the laboratory, particularly the weight loss tests.

Deyab et al..$^{14}$ investigated the corrosion by NAs using a carbon-steel alloy, as well as the inhibitory effect caused by some ethoxylated fatty acids through the voltammetry technique. ${ }^{14}$ They observed that the corrosion rate was critically dependent on the type of NA component of the matrix. The corrosion rate proportionally increased as a function of the molar weight of the naphthenic acid, reaching a maximum value in the presence of acid species with a carbon number equal to 9 , i.e., $\mathrm{C}_{9}$, and then the corrosion rate decreased. In 2014, Dias et al. ${ }^{15}$ used atomic force microscopy (AFM) and scanning electron microscopy (SEM) to monitor the thermal degradation of NAs present in two crude oils and their corrosion effects on AISI 1020 steel. Two acidic crude oils samples $(\mathrm{TAN}=2.38$ and $4.79 \mathrm{mg} \mathrm{KOH} \mathrm{g}^{-1}$, and total sulfur $=0.7993$ and 1.0220 wt.\%) were submitted to thermal treatment at 280 , 300 and $350{ }^{\circ} \mathrm{C}$ during 2,4 and $6 \mathrm{~h}$. AFM topographic profile evidenced that the naphthenic acid corrosion of the crude oil with TAN of $4.73 \mathrm{mg} \mathrm{KOH} \mathrm{g}^{-1}$ on AISI 1020 steel was profoundly altered, having a marked reduction in peakto-peak height values (obtained by subtracting the value of the lowest peak by the highest peak in the topographic area examined). Light microscopy (LM) images and microphotographs confirmed the presence of irregularities, characterizing the corrosion mechanism as pitting type. The naphthenic corrosion is also evidenced in samples with low TAN value $\left(0.44 \mathrm{mg} \mathrm{KOH} \mathrm{g}^{-1}\right) .{ }^{16}$ In 2015, the same group studied the corrosion process on an AISI 316 steel surface by LM, AFM and Raman spectroscopy during a total period of 36 days at ambient conditions $\left(\mathrm{T}=25^{\circ} \mathrm{C}\right.$ and $\mathrm{p}=1 \mathrm{~atm}) .{ }^{16}$ The steel material was immersed in two crude oil samples $(\mathrm{G}$ and $\mathrm{J})$ with distinct TAN values ( 0.33 and $3.10 \mathrm{mg} \mathrm{KOH} \mathrm{g}^{-1}$ ). For LM images, the naphthenic corrosion was evidenced only on the AISI 316 steel surface from 21 days of exposure to sample J. Conversely, AFM measurements predicted the "real stage" of naphthenic corrosion, evidenced by topographic and phase images from 21 days for crude oil $\mathrm{G}$ and 14 days for sample J. Raman spectra also corroborated with the AFM data, wherein three corrosion products were identified: goethite $(\alpha-\mathrm{Fe}(\mathrm{OOH}))$, magnetite $\left(\mathrm{Fe}_{3} \mathrm{O}_{4}\right)$, and hematite $\left(\mathrm{Fe}_{2} \mathrm{O}_{3}\right){ }^{16}$

Despite the promising results obtained until this moment, only a few studies associate the rate and the type of corrosion with microscopic analyzes. Herein, a typical Brazilian acidic crude oil (TAN $=2.1390 \mathrm{mg} \mathrm{KOH} \mathrm{g}^{-1}$ and $\mathrm{S}=0.7778$ wt. \%) was submitted to thermal degradation as a function of time $(t=6,12,24,36,48$ and $72 \mathrm{~h})$. The corrosion rate was monitored on the specimens of AISI 1020 steel, where the obtained results were associated with physicochemical parameters such as weight loss, TAN, and total sulfur content, as well as with microscopic analyzes (LM, AFM, and SEM/energy dispersive spectroscopy (EDX)).

\section{Experimental}

\section{Material and reagents}

Propan-2-ol, toluene and potassium hydroxide $(\mathrm{KOH}$, analytical grade with purity greater than $99.5 \%$, Vetec Química Fina Ltda, Brazil) were used for the TAN measurements. Water sandpapers, with granulometry from 80 to $2000 \mathrm{~cm}^{2}$, acetone and kerosene (Vetec Química Fina Ltda, Brazil) were used in the polishing and washing of AISI 1020 steel used in the weight loss experiments. Clark solution (prepared from $1 \mathrm{~L}$ hydrochloric acid $(\mathrm{HCl})$ solution containing 20.00 and $50.00 \mathrm{~g}$ of antimony chloride III, $\mathrm{SbCl}_{3}$, and stannous chloride III, $\mathrm{SnCl}_{2}$, respectively) was used in the pickling of carbon steel according to the ASTM G31-72. ${ }^{13}$

\section{Crude oil characterization}

A heavy crude oil sample was selected from the production field located in the sedimentary basin of the 
Brazilian coast. The characterization properties were then determined (Table 1) according to each standard ASTM methods by the Petroleum Characterization Laboratory of the Federal University of Espírito Santo (LabPetro, UFES, Brazil). Water content was determined by potentiometric Karl Fischer (KF) titration, by ASTM D4377. ${ }^{17}$ The solvent used in the analysis was a mixture of methanol and chloroform $20 \%(\mathrm{v} / \mathrm{v})$. For the standardization of the KF reagent, distilled water was solubilized into the solvents. A Metrohm KF titrator (model 836 Titrando, Switzerland) equipped with a double platinum electrode was employed for the water content determination tests. Density was determined in compliance with ISO $12185,{ }^{18}$ by injecting the sample into the digital automatic analyzer Stabinger SVM 3000 (Anton Paar, Austria). American Petroleum Institute (API) gravity was also reported according to ASTM D1250. ${ }^{19}$ TAN was determined in compliance with the ASTM D664 by potentiometric titration (Metrohm 836 automatic titrator, Switzerland) of the sample, using an alcoholic solution of $\mathrm{KOH} .{ }^{20}$ The total sulfur content was analyzed according to the ASTM D4294 standard by energy-dispersive X-ray fluorescence spectrometry using the automatic analyzer HORIBA, model SFLA-2800, Japan. ${ }^{21}$

Table 1. Physicochemical properties of the virgin crude oil

\begin{tabular}{lc}
\hline Property & Result \\
\hline Water content / $(\% \mathrm{v} / \mathrm{v})$ & $0.395 \pm 0.006$ \\
Density at $20{ }^{\circ} \mathrm{C} /\left(\mathrm{g} \mathrm{cm}^{-3}\right)$ & $0.9739 \pm 0.0002$ \\
API gravity at $60 \mathrm{~F}$ & $13.2 \pm 1.0$ \\
Total acid number $/\left(\mathrm{mg}\right.$ of $\left.\mathrm{KOH} \mathrm{g}^{-1}\right)$ & $2.139 \pm 0.01598$ \\
Sulfur content $/(\% \mathrm{~m} / \mathrm{m})$ & $0.7788 \pm 0.0002$ \\
\hline
\end{tabular}

API: American Petroleum Institute.

Immersion experiments of the AISI 1020 steel

AISI 1020 steel samples (area of $30 \mathrm{~cm}^{2}$ ) were washed with acetone, polished with 120-1220 grit sandpaper, immersed in an ultra-sonication bath (model USC 1400A, Unique, USA) with acetone under $20 \mathrm{~min}$ at $40 \mathrm{~Hz}$ and subsequently submitted to the petroleum immersion test.

The corrosion tests consisted in the contact of the AISI 1020 steel with the crude oil at $320^{\circ} \mathrm{C}$ with time ranging from $6,12,24,36,48$ and $72 \mathrm{~h}$. For these corrosion assays, an autoclave (model 4848, Parr Instrument Company, Moline, USA) was used, being previously adjusted with an average heating ramp of $2{ }^{\circ} \mathrm{C} \mathrm{min}^{-1}$, which working temperature $\left(320^{\circ} \mathrm{C}\right)$ is reached after $3 \mathrm{~h}$; the rotation and pressure were of $210 \mathrm{rpm}$ and $110 \mathrm{psi}$, respectively. The volume of crude oil used in each experiment was equal to $1 \mathrm{~L}$. A total of four AISI 1020 steel specimens were used for each experiment, one of them was used for the studies of SEM/EDX and AFM analyses whereas the other three were used for the weight loss assays.

\section{Weight loss experiments}

After the corrosion assay, AISI 1020 steel samples were washed with kerosene and then with acetone, and dried with hot air. Steel samples were submersed for $5 \mathrm{~s}$ in two beakers, one containing a pickling (Clark) solution and another only distilled water. This procedure was carried out several times until the weight of the samples showed a minimum variation containing an uncertainty of $\pm 0.0001 \mathrm{~g} \cdot{ }^{13}$

After the weight determination of steel samples submitted to corrosion assays, the corrosion rate was calculated from equation 4, according to ASTM G31-72 norm. ${ }^{13}$

Corrosion rate $=\frac{(\mathrm{K} \times \mathrm{W})}{(\mathrm{A} \times \mathrm{T} \times \mathrm{D})}$

where $\mathrm{K}$ is equal to $8.76 \times 10^{4} ; \mathrm{T}$ is the exposure time in hours; $\mathrm{A}$ is the area of the specimen in $\mathrm{cm}^{2} ; \mathrm{W}$ is relative to the weight loss of the specimen in $\mathrm{g}$ (difference between initial and final weight of steel samples); and D represents the density of the specimen in $\mathrm{g} \mathrm{cm}^{-3}$. The results are described in Table 2.

\section{SEM/EDX and AFM}

The SEM and AFM analysis were performed in situ before (blank sample) and after exposure of the AISI 1020 steel to the crude oil, submitted or not to pickling procedure with the Clark solution.

The images of SEM/EDX were performed on the Zeiss equipment (model VO-MA10, Oxford instruments, Germany), operating at $20 \mathrm{kV}$. The AFM analysis was performed using an Alpha 300R confocal microscope (WITec, Wissenschaftliche Instrumente und Technologie GmbH, Ulm, Germany). For the AFM analyses, the topographic images were performed in the non-contact mode (in the regions selected by the use of the light microscope, coupled to the Witec equipment), with cantilever tips of $\mathrm{Si}_{3} \mathrm{~N}_{4}$, nominal constant of $42 \mathrm{~N} \mathrm{~m}^{-1}$, resonance frequency of ca. $285 \mathrm{kHz}$, scan rates of $0.3-1.0 \mathrm{~Hz}$ and scan size of 2,500-10,000 nm.

To evaluate the roughness of the topographic images, the parameters of surface asymmetry (Ssk), kurtosis (Sku) and peak-peak height, were used. ${ }^{22,23}$ Negative asymmetry indicates a predominance of valleys, whereas a positive 
Table 2. Corrosion rate and weight loss values of AISI 1020 steel submitted to corrosion assays in crude oil (total acid number $\left(\right.$ TAN) $=2.139 \mathrm{mg}^{\circ}$ of KOH g ${ }^{-1}$ and total sulfur $(\mathrm{S})=0.7788 \mathrm{wt} . \%)$ as a function of the thermal degradation time at $320^{\circ} \mathrm{C}$

\begin{tabular}{lccccc}
\hline time $(\mathrm{t}) / \mathrm{h}$ & $\begin{array}{c}\text { Constant }(\mathrm{K}) / \\
\left(\mathrm{mm} \text { year }{ }^{-1}\right)\end{array}$ & $\begin{array}{c}\text { Weigth loss } \\
\left(\mathrm{W}=\mathrm{m}_{0}-\mathrm{m}_{\mathrm{f}}\right) / \mathrm{g}\end{array}$ & Area $(\mathrm{A}) / \mathrm{cm}^{2}$ & Density $\left.(\mathrm{D}) /(\mathrm{g} \mathrm{cm})^{-3}\right)$ & $\begin{array}{c}\text { Corrosion rate } / \\
\left(\mathrm{mm} \mathrm{year}^{-1}\right)\end{array}$ \\
\hline 0 & $8.76 \times 10^{4}$ & 0.0000 & 30.5140 & $8.6851 \pm 0.0002$ & 0.0000 \\
6 & $8.76 \times 10^{4}$ & 0.0216 & 30.0589 & $8.1665 \pm 0.0002$ & $2.8375 \pm 0.5494$ \\
12 & $8.76 \times 10^{4}$ & 0.0361 & 30.4764 & $8.6243 \pm 0.0002$ & $2.2684 \pm 3.8992$ \\
24 & $8.76 \times 10^{4}$ & 0.0610 & 30.4676 & $8.6999 \pm 0.0002$ & $1.8952 \pm 0.0264$ \\
36 & $8.76 \times 10^{4}$ & 0.0855 & 29.9184 & $8.2768 \pm 0.0002$ & $1.9008 \pm 0.0813$ \\
48 & $8.76 \times 10^{4}$ & 0.1246 & 30.2985 & $8.2958 \pm 0.0002$ & $2.0401 \pm 0.0175$ \\
72 & $8.76 \times 10^{4}$ & 0.1792 & 30.4087 & $8.3028 \pm 0.0002$ & $1.8769 \pm 0.0702$ \\
\hline
\end{tabular}

asymmetry indicates the formation of peaks. ${ }^{23}$ The peak-peak height is determined by subtracting the value of the highest peak from the lowest peak value in the specific topographic area. ${ }^{22}$

The Ssk is determined by equation 5 , that measures the difference of symmetry of the profile with regard to the median plane, where $R_{Q}$ is the root mean square of the height deviation; $\mathrm{n}$ is the number of points within the image grid and $\mathrm{Z}$ is the height of the surface with regard to the median plane. In general, when Ssk = zero, it suggests symmetric data distribution or even around the mean plan; when Ssk $\neq$ zero, an asymmetric distribution is suggested, where a flat surface with small peaks $($ Ssk $>0)$ or small valleys $($ Ssk $<0)$ can be observed.

$\mathrm{Ssk}=\frac{1}{\mathrm{R}_{\mathrm{Q}}^{3}} \frac{1}{\mathrm{n}} \sum_{\mathrm{i}=1}^{\mathrm{n}} \mathrm{Z}_{\mathrm{i}}^{3}$

Sku is determined by equation 6 and indicates whether the data are arranged horizontally or perpendicularly over the average. Sku $>3.00$ indicates the presence of excessively high peaks or deep valleys, while Sku $<3.00$ indicates surfaces with protruding texture. Finally, when the surface heights are normally distributed, the Sku value is equal to $3.00 .{ }^{22}$

$\mathrm{Sku}=\frac{1}{\langle\mathrm{MN}\rangle \mathrm{SQ}^{4}} \sum_{\mathrm{j}=1}^{\mathrm{N}} \sum_{\mathrm{i}=1}^{\mathrm{M}} \epsilon_{\mathrm{i}, \mathrm{j}}\left[\mathrm{Z}\left(\mathrm{x}_{\mathrm{ij}, \mathrm{y}} \mathrm{y}\right)-\overline{\mathrm{Z}}\right]^{4}$

where $\mathrm{M}$ and $\mathrm{N}$ are the number of data points in $\mathrm{x}$ and $\mathrm{y}$, respectively; and $\mathrm{SQ}$ is the square roughness average.

\section{Raman spectroscopy}

Similar to AFM and SEM, Raman spectra were collected in situ before and after exposure of AISI 1020 steel to the petroleum, as well as after washing with Clark solution. The Raman spectra were obtained using an Nd:YAG laser (wavelength $=532 \mathrm{~nm}$ ) and a Nikon lens with the precision of $100 \times(\mathrm{NA}=0.90)$ as the excitation source. For each spectrum, an integration time of $100 \mathrm{~ms}$ was used. ${ }^{15}$

\section{Results and Discussion}

\section{Corrosion rate and physicochemical characterization of the petroleum}

The total sulfur (S) and TAN values of the crude oil in function of corrosion experiments are shown in Table 3. For the original crude oil, the TAN and total S content were of $2.139 \mathrm{mg}$ of $\mathrm{KOH} \mathrm{g}^{-1}$ and $0.7788 \mathrm{wt} . \%$, respectively. After the thermal degradation, a reduction of 37 and $8 \%$ were observed in the TAN and the total S content at $320^{\circ} \mathrm{C}$ and $72 \mathrm{~h}$, respectively $\left(\mathrm{TAN}_{72 \mathrm{~h}}=1.354 \mathrm{mg}\right.$ of $\mathrm{KOH} \mathrm{g} \mathrm{g}^{-1}$ and $\mathrm{S}_{72 \mathrm{~h}}=0.7209 \mathrm{wt} . \%$ ). These results suggest that, unlike the NAs, the sulfur heteroatom compounds remained stable after thermal degradation of crude oil, thus, proving its greater thermal stability. ${ }^{24-26}$ According to the literature, the NAs may undergo thermal degradation reactions and produce species of short chain $\left(\mathrm{C}_{1}-\mathrm{C}_{4}\right)$, which are enhanced by their low aromaticity degree and may also undergo decarboxylation reactions as a consequence of its low thermal stability. ${ }^{11,27}$

Figures $1 \mathrm{a}$ and $1 \mathrm{~b}$ show the plots of TAN/weight loss and TAN/corrosion rate versus thermal degradation time. In general, it is possible to observe that there is a linear behavior in the reduction of TAN in function of thermal degradation. In contrast, a linear increase is observed for the weight loss curve of AISI 1020 steel samples (Figure 1a). On the other hand, the corrosion rate presents an exponential decay over time, becoming constant from $\mathrm{t}=24 \mathrm{~h}$. The sulfur compounds in petroleum are often corrosive; however, the corrosion product of them, such as iron sulfide $(\mathrm{FeS})$, can act in the production of a protective pellicle on the surface of the metal. The types of sulfur compounds species allied to their concentration are factors 
Table 3. Physicochemical properties (TAN and total $\mathrm{S}$ content) of the crude oil as a function of the thermal degradation time at $320^{\circ} \mathrm{C}$

\begin{tabular}{cccccc}
\hline Temperature $/{ }^{\circ} \mathrm{C}$ & time $/ \mathrm{h}$ & TAN $/\left(\mathrm{mg}\right.$ of $\left.\mathrm{KOH} \mathrm{g}^{-1}\right)$ & TAN reduction $/ \%$ & Sulfur $/(\% \mathrm{~m} / \mathrm{m})$ & Sulfur reduction $/ \%$ \\
\hline 0 & $2.139 \pm 0.016$ & - & $0.7788 \pm 0.0002$ & - \\
& 6 & $1.973 \pm 0.031$ & 7.77 & $0.7657 \pm 0.0003$ & 1.68 \\
320 & 12 & $1.757 \pm 0.001$ & 17.86 & $0.7510 \pm 0.001$ & 2.41 \\
& 24 & $1.929 \pm 0.019$ & 9.21 & $0.7532 \pm 0.0002$ & 3.28 \\
\\
36 & $1.672 \pm 0.016$ & 21.88 & $0.7736 \pm 0.0005$ & 0.66 \\
& 48 & $1.736 \pm 0.022$ & 18.82 & $0.7483 \pm 0.0001$ & 3.91 \\
& 72 & $1.354 \pm 0.012$ & 36.72 & $0.7209 \pm 0.0002$ & 7.43 \\
\hline
\end{tabular}

TAN: total acid number.

that affect the corrosive process of crude oil. ${ }^{28,29}$ The results of weight loss illustrated in the Figure 1a suggest the possibility of formation of a passivation layer (probably being composed of $\mathrm{FeS}$, equations 2 and 3) under the surface of the AISI 1020 steel, which acts inhibiting the corrosion mainly after $24 \mathrm{~h}$ of degradation.

The literature reports that naphthenic acidity, TAN, temperature, and sulfur content directly influence the rate of corrosion..$^{3,10,30}$ Alvisi et al..$^{30}$ showed the influence of temperature on the corrosion rate of a system with TAN $=2 \mathrm{mg}$ of $\mathrm{KOH} \mathrm{g}^{-1}$. It was observed that increasing the temperature from 204 to $371{ }^{\circ} \mathrm{C}$, the corrosion rate increased by $400 \%\left(0.30 \rightarrow 1.27 \mathrm{~mm}\right.$ year $\left.^{-1}\right)$. Conversely, when the temperature was kept constant at $371{ }^{\circ} \mathrm{C}$ and the TAN varied ( 2 to $10 \mathrm{mg}$ of $\mathrm{KOH} \mathrm{\textrm {g } ^ { - 1 }}$ ), the corrosion rate increased from 1.27 to $2.08 \mathrm{~mm}$ year $^{-1}{ }^{10}$ In 2014 , Sixian et $a l .^{12}$ investigated the behavior of naphthenic corrosion as a function of temperature and of the discharge angle, where the authors also confirmed that the temperature has a preponderant effect on the corrosion

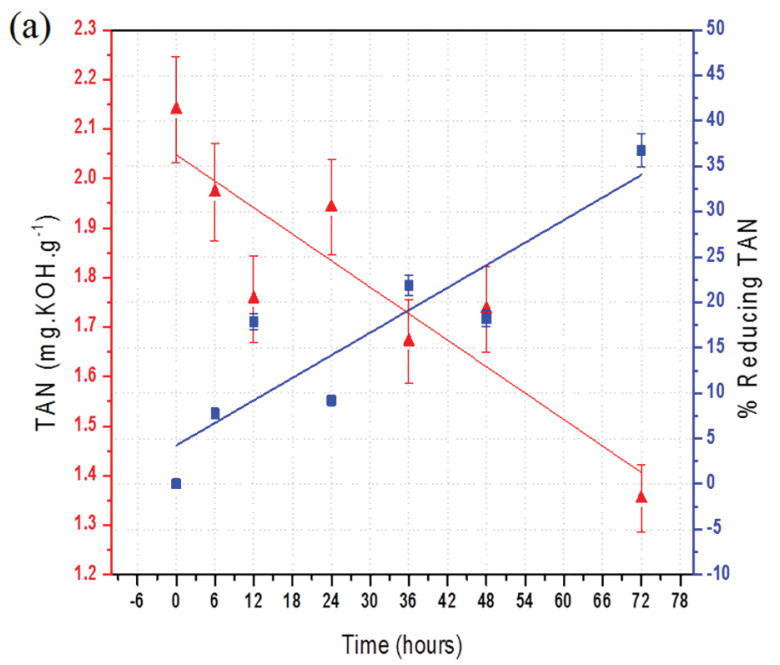

rate. When the specimens were analyzed by microscopic techniques, it was observed that the corrosion proceeded from the grain boundary to inner grain. ${ }^{12}$ It is known that naphthenic corrosion becomes more severe at temperatures above $200^{\circ} \mathrm{C}$, since the temperature facilitates the diffusion of NAs molecules to the metal surface, due to an increase of their solubility in oil. ${ }^{30}$ However, studies show that in addition to temperature and TAN, the molecular structure of NAs is a preponderant factor in the determination of petroleum corrosivity. ${ }^{31}$

Figure 2 shows the images of LM for virgin AISI 1020 steel (blank, Figure 2A), as a function of the degradation time in crude oil, before (Figures 2B-2G) and after (Figures 2H-2M) washing with Clarke's solution. The LM image of the non-exposed petroleum steel (Figure 2A) reveals a characteristic polishing profile from the pretreatment of the specimens with grit sandpaper.

Evaluating the surface of AISI 1020 steel as a function of the corrosion experiments after $6 \mathrm{~h}$ of degradation, it was possible to observe the formation of a passivation

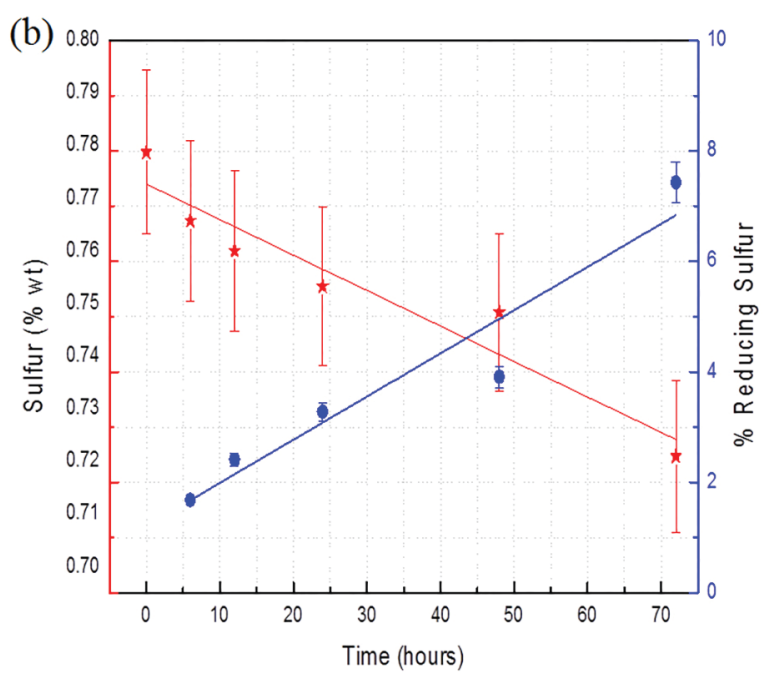

Figure 1. (a) TAN/mass loss, and (b) TAN/corrosion rate curves over AISI 1020 steel samples in function of degradation time (from 6 to 72 h) submitted to the immersion experiments in the crude oil with TAN of $2.139 \mathrm{mg}$ of $\mathrm{KOH} \mathrm{g}^{-1}$ and total S content of 0.7788 wt. $\%$. 


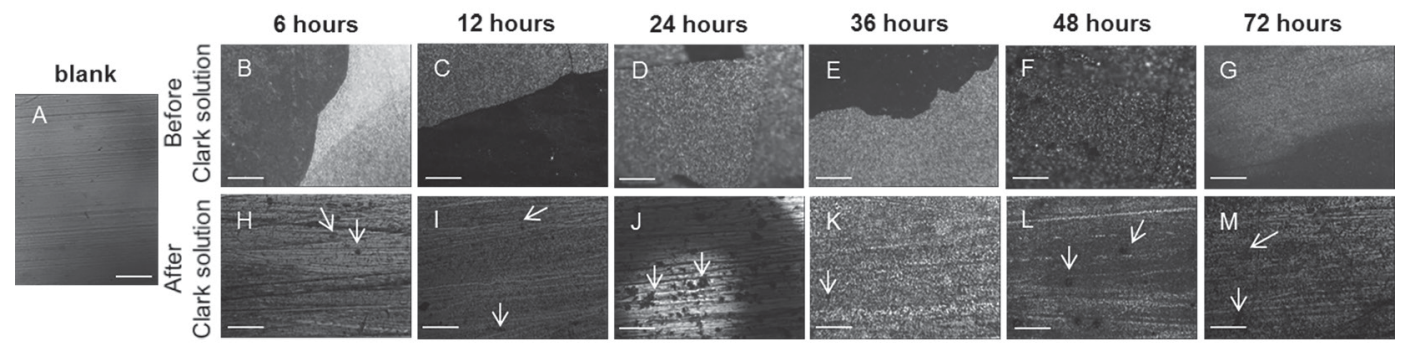

Figure 2. LM analysis of 1020 steel specimens (A) before (blank) and (B-M) after immersion in crude oil as a function of thermal degradation time (from 6 to $72 \mathrm{~h}$ ) at $320^{\circ} \mathrm{C}$. Note that the (B-G) corresponds to 1020 steel samples not submitted to cleaning solution (Clark solution), where light phases correspond to sulfide layer formation. The corrosion is only observed for the 1020 steel samples submitted to cleaning solution (H-M), where the arrows indicate a pitting-type corrosion. White scales, located below in the left-corner of all images, corresponding to a size of $60 \mu \mathrm{m}$.

film on the surface of the steel (Figures 2B-2G). This film is composed of two layers, one light (external) and the other dark (internal), overlapping at $\mathrm{t}=48 \mathrm{~h}$, and these layers were removed by Clarke's solution (Figures $2 \mathrm{H}-2 \mathrm{M}$ arrows), showing the effect of corrosion on the steel surface, where corrosion points are now clearly observed on the surface of the steel.

SEM/EDX analyses (Figure 3 and Table 4) were also employed in these studies because they presented a spatial resolution higher than of LM. ${ }^{23,32}$ SEM/EDX analyses reveal that the light layer (external) is characterized by sulfur crystals and the dark layer (internal) by a homogeneous layer of iron oxides and oxyhydroxides (Figures 3B-3F and Table 4). This morphology is altered after $48 \mathrm{~h}$ of thermal degradation (Figure 3F), where the formation of a single layer occurs and is composed of crystals of $\mathrm{FeS}$ (Figure 3G).

The chemical composition of the two layers produced in the corrosion process was confirmed by the EDX technique (Table 4) and by Raman spectroscopy (Figure 4). FeS was identified in the external layer, whereas iron oxide and oxyhydroxide were identified in darker internal layer. ${ }^{33} \mathrm{FeS}$ is characterized as a corrosion product, and its formation is explained by equations 1-3, as previously described. ${ }^{34}$

Although EDX spectra indicate Fe as the main element in both layers (data not shown), it is also possible to identify other elements such as $\mathrm{C}, \mathrm{Mn}, \mathrm{Mo}$, and $\mathrm{Si}$, which are characteristic of the chemical composition of AISI 1020 carbon steel (Table 4). The carbon steel material is mainly composed of $\mathrm{Fe}$ and $\mathrm{C}$ and other residual elements such as $\mathrm{Mn}, \mathrm{P}, \mathrm{Si}, \mathrm{Ni}$, and $\mathrm{Cr}^{35}$ The presence of $\mathrm{Si}$ could be explained by the use of the sandpaper in the pretreatment of the specimen.

After washing the specimens with Clarke's solution, mainly for the time interval of $\mathrm{t}=12 \mathrm{~h}$, it is evident the generalized corrosion formation on the steel surface (Figures 3H-3M). The EDX data (Table 4) indicates the absence of S, confirming the complete removal of the passivation layer. The circled area of Figure $3 \mathrm{H}$ shows the beginning of the formation of corrosion points on the steel surface, being consistent with the results obtained by

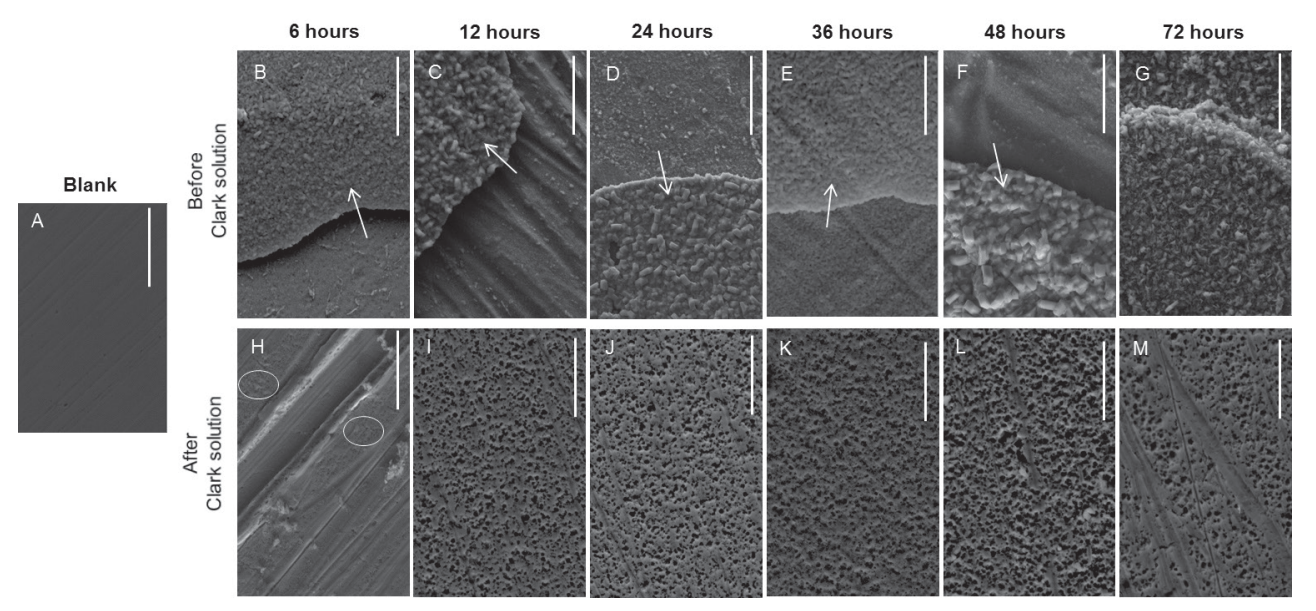

Figure 3. SEM analysis of 1020 steel (A) before (blank) and (B-M) after immersion in crude oil as a function of thermal degradation time (from 6 to $72 \mathrm{~h}$ ) at $320^{\circ} \mathrm{C}$. (B-G) 1020 steel samples not submitted to cleaning solution (Clark solution), where the arrows clearly indicate the light phase observed by $\mathrm{LM}$, referring to the formation of sulfide layer, whereas the corrosion is only evidenced $(\mathrm{H}-\mathrm{M})$ at a time of $12 \mathrm{~h}$. In this case, it is necessary cleaning the AISI 1020 steel surface with the Clark solution to observe de corrosion process. The circled area in Figure $3 \mathrm{H}(\mathrm{t}=6 \mathrm{~h})$ indicates small points of corrosion. White scales bars, located in the upper right corner of all the images, corresponds to a size of $5 \mu \mathrm{m}$. 
Table 4. EDX results for the AISI 1020 steel samples surface without and with cleaning solution treatment (Clark solution) in function of thermal degradation time (from 0 to $72 \mathrm{~h}$ ) at $320^{\circ} \mathrm{C}$

\begin{tabular}{|c|c|c|c|c|c|c|c|c|c|}
\hline \multirow{2}{*}{$\begin{array}{l}\text { Degradation } \\
\text { time } / \mathrm{h}\end{array}$} & \multirow{2}{*}{ Sample } & \multicolumn{8}{|c|}{ Detected element } \\
\hline & & $\mathrm{Fe}$ & $\mathrm{C}$ & $\mathrm{O}$ & $\mathrm{S}$ & $\mathrm{Mn}$ & Mo & $\mathrm{F}$ & $\mathrm{Si}$ \\
\hline 0 & blank & + & + & - & - & + & - & + & + \\
\hline \multirow[t]{2}{*}{6} & before Clark solution (layer sulfide) & + & + & - & + & - & - & - & - \\
\hline & after Clark solution & + & - & - & - & + & - & + & - \\
\hline \multirow[t]{2}{*}{12} & before Clark solution (layer sulfide) & + & + & - & + & - & + & - & - \\
\hline & after Clark solution & + & + & + & - & + & - & + & - \\
\hline \multirow[t]{2}{*}{24} & before Clark solution (layer sulfide) & + & + & - & + & - & - & - & - \\
\hline & after Clark solution & + & + & - & - & - & - & + & - \\
\hline \multirow[t]{2}{*}{36} & before Clark solution (layer sulfide) & + & - & - & + & + & - & - & - \\
\hline & after Clark solution after stripping & + & + & - & - & + & - & + & - \\
\hline \multirow[t]{2}{*}{48} & before Clark solution (layer sulfide) & + & + & - & + & - & + & - & - \\
\hline & after Clark solution & + & + & + & - & - & - & + & - \\
\hline \multirow[t]{2}{*}{72} & before Clark solution (layer sulfide) & + & + & + & + & - & - & - & - \\
\hline & after Clark solution & + & + & + & - & + & - & + & - \\
\hline
\end{tabular}

Qualitative data: + and - correspond, respectively, to the presence and absence of elements.

Sixian et al. ${ }^{12}$ which they studied the naphthenic corrosion over high temperatures on SA210C and A335P5 steels. ${ }^{12}$ Rios et al. ${ }^{29}$ observed similar results, which studied the

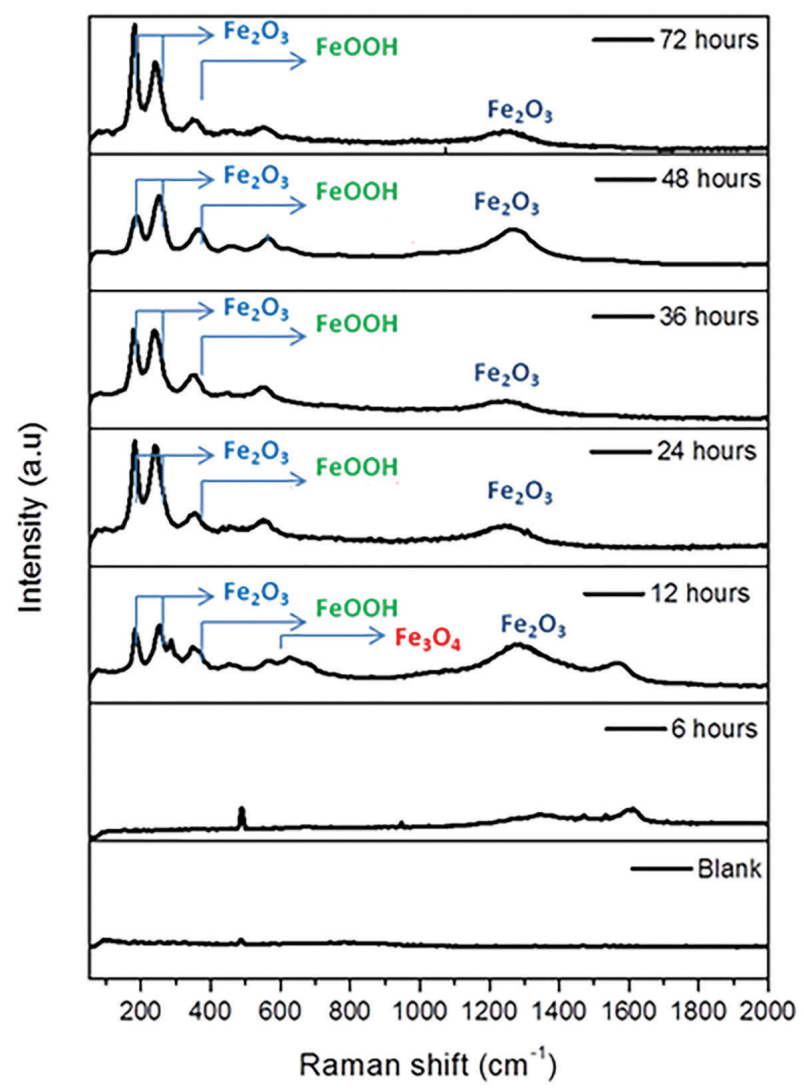

Figure 4. Raman spectra of the AISI 1020 steel samples of virgin surface and after the exposure to the crude oil samples as a function of degradation time before washing with Clark's solution. corrosion on the steel surface exposed to crude oil with different concentrations of sea water, NAs, and $\mathrm{H}_{2} \mathrm{~S} .{ }^{29}$

AFM analysis is a unique technique able to evaluate nanostructural changes on the steel surface, allowing a more accurate identification of the corrosion processes. ${ }^{16}$ Figures 5-6 show the topography image and cross-section of the topographic profile of the surface of the virgin AISI 1020 steel, before (Figures 5b-5c and 6b-6c), and after (Figures 6d-6o) washing with Clarke's solution.

Figures $5 b-5 c$ and $6 b-6 c$ show that the topographic profile of the blank is characterized by the pretreatment of the steel with the grit sandpaper, having a roughness pattern with a peak-to-peak height of $67.41 \mathrm{~nm}$, values of Ssk $<0$ and $\mathrm{Sku}>3$, data that characterize the predominance of valleys on the steel surface.

In Figures 5d-5e, where AISI 1020 steel was exposed to $6 \mathrm{~h}$ of corrosion, it is possible to observe strong changes on its surface. The topographic profile indicates mainly changes in the values of peak-to-peak height $(553.36 \mathrm{~nm})$ and Ssk (Ssk $>0)$, characterized by the formation of peaks on the steel surface (Table 5). These values are influenced by the formation of the passivation layer as observed by the LM and SEM/EDX data.

The values of peak-to-peak height increased during the corrosion process, reaching a maximum at $\mathrm{t}=24 \mathrm{~h}$ of degradation (1037.99 nm, Table 5) with Ssk ca. 0 and $\mathrm{Sku}>3$. This data is confirmed by the observation of a peak above $290 \mathrm{~nm}$ in this time interval (Figures 5h-5i). In Table 5, it is attributed all numerical values of peak-to-peak height, Ssk and Sku observed by AFM on the surface of AISI 1020 steel (Figures 5d-5o). 

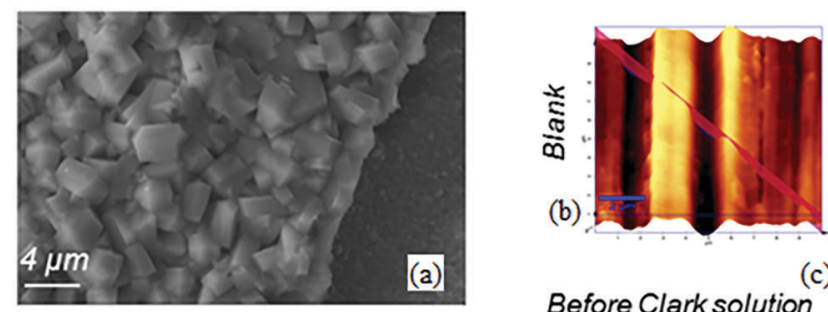

(a)
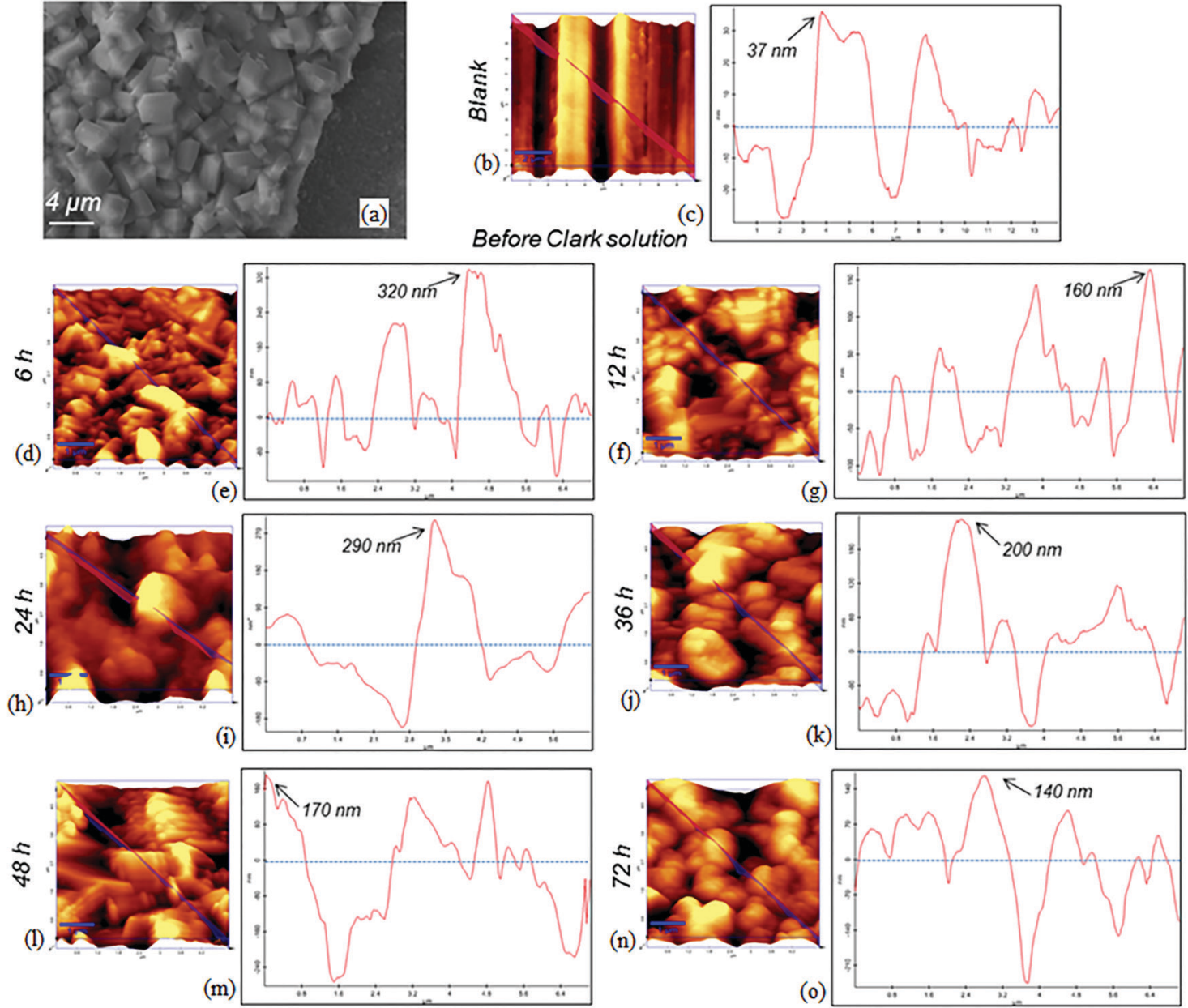

Figure 5. (a) SEM of 1020 steel, after immersion in the oil. The circled area represents the sulfide layer, which was studied by AFM analysis as a function of degradation time (b-o). (b, c) 1020 steel before the immersion in oil (blank); (d-o) immersion in the oil from 6 to $72 \mathrm{~h}$ and non-submitted to washing with Clark's solution. The arrows indicate the formation of peaks or valleys. Scale bar $=1 \mu \mathrm{m}$.

A greater topographic change is notoriously observed at time intervals of $\mathrm{t}=24$ and $48 \mathrm{~h}$. After $\mathrm{t}=72 \mathrm{~h}$ of exposure to petroleum, a decrease in the peak-to-peak values is noticed, because in this period, as shown by SEM and LM images (Figure 3G), there is a total and uniform coverage of the FeS layer on the AISI 1020 steel surface.

After removal of the passivation layer from the surface of AISI 1020 steel by Clarke's solution (Figure 6), changes on the steel surface are observed up to $6 \mathrm{~h}$ of degradation (Table 5), with the predominance of valleys on the surface of the steel, corroborating again with the data presented by SEM/EDX (Figure 5 and Table 5). These data indicate the importance of AFM analysis to predict or diagnose nanostructural changes with greater sensitivity than LM and SEM/EDX techniques. Similar to AFM data without Clark's solution, the values for the formation of valleys increase progressively up to the time interval of $t=48 \mathrm{~h}$ (Figure $6 \mathrm{~m}$ ). After this period, valleys of peak-to-peak height decrease $(t=72 \mathrm{~h})$, due to the high change in the steel surface.

\section{Raman spectroscopy}

Figure 4 shows a compilation of Raman spectroscopy data for AISI 1020 steel at different degradation time intervals of degradation. From $t=12 \mathrm{~h}$, it was observed the appearance of peaks in the regions between 100 and $1800 \mathrm{~cm}^{-1}$. The compounds identified were $\alpha-\mathrm{Fe}_{2} \mathrm{O}_{3}$ (hematite, 220, 298 and $1300 \mathrm{~cm}^{-1}$ ), $\alpha$-FeOOH (goethite, $385 \mathrm{~cm}^{-1}$ ) and $\mathrm{Fe}_{3} \mathrm{O}_{4}$ (magnetite, $660 \mathrm{~cm}^{-1}$ ). $\alpha$-FeOOH could be formed from the reaction with dissolved oxygen in the petroleum and small amounts of water (equation 7). Also, the presence of species such as $\mathrm{H}_{2} \mathrm{~S}, \mathrm{RSH}$, and $\mathrm{RCOOH}$ may also contribute to its formation. Due to the temperature action $\left(\mathrm{T}=320^{\circ} \mathrm{C}\right), \alpha-\mathrm{FeOOH}$ can undergo a dehydration reaction and be converted to $\mathrm{Fe}_{3} \mathrm{O}_{4}$ (equation 8), and subsequently, $\mathrm{Fe}_{3} \mathrm{O}_{4}$ can be oxidized to $\alpha-\mathrm{Fe}_{2} \mathrm{O}_{3}$ (equation 9). ${ }^{36,37}$

$4 \mathrm{Fe}+3 \mathrm{O}_{2}+2 \mathrm{H}_{2} \mathrm{O} \rightarrow 4 \mathrm{FeOOH}$

$8 \mathrm{FeOOH}+\mathrm{Fe} \rightarrow 3 \mathrm{Fe}_{3} \mathrm{O}_{4}+4 \mathrm{H}_{2} \mathrm{O}$

$2 \mathrm{Fe}_{3} \mathrm{O}_{4}+1 / 2 \mathrm{O}_{2} \rightarrow 3 \mathrm{Fe}_{2} \mathrm{O}_{3}$ 

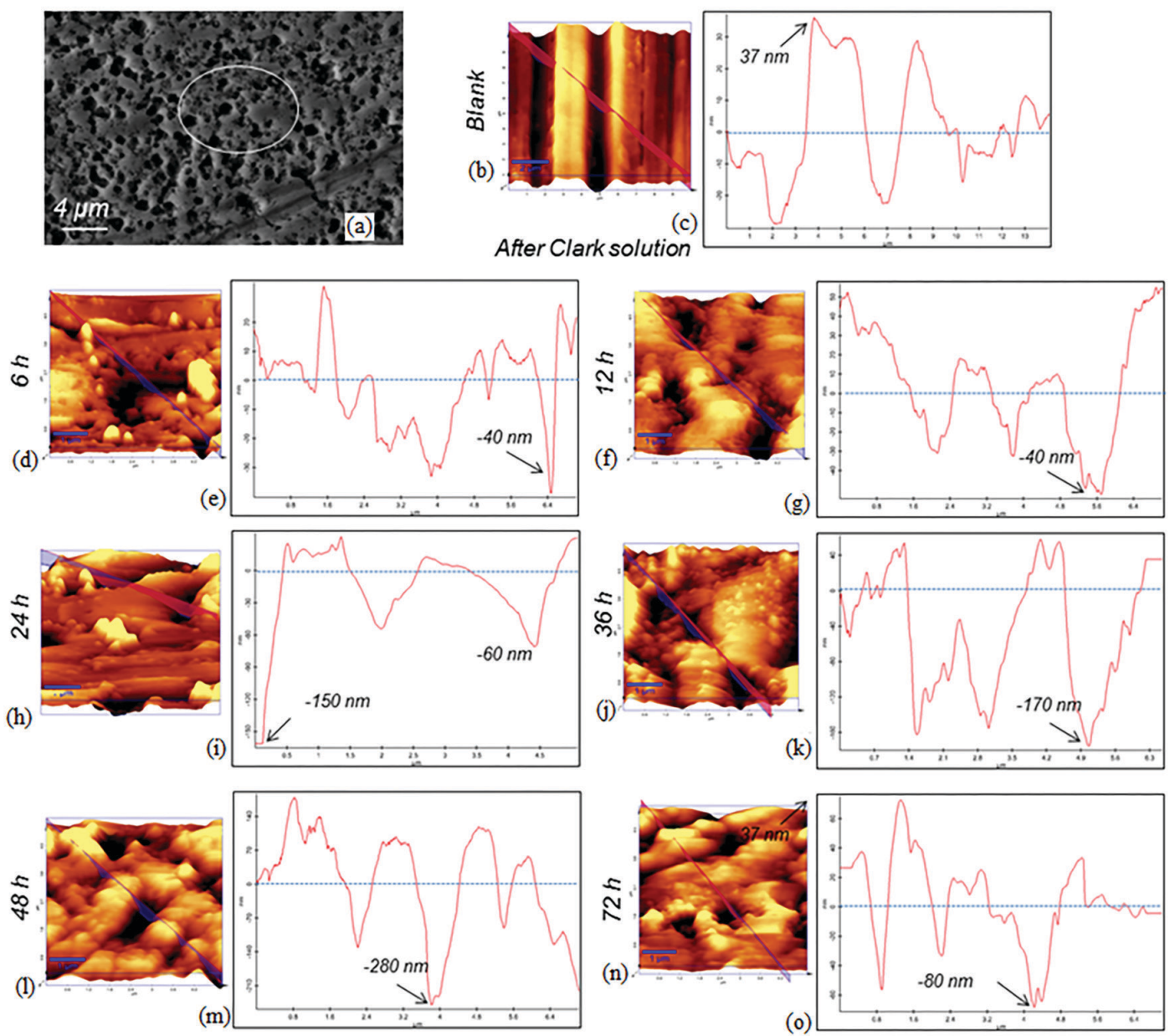

Figure 6. (a) SEM of 1020 steel after immersion in the oil, and pickled, posteriorly. The circled area represents the studied area by AFM in different time intervals (b-o); (b, c) 1020 steel before immersion in crude oil (blank); (d-o) immersion to the crude oil (from 6 to 72 h) and washed with Clark's solution. The arrows indicate the formation of valleys. Scale bar $=1 \mu \mathrm{m}$.

Table 5. Analysis of the topographic parameters (peak-peak height; Ssk and Sku) for 1020 steel, exposure to the petroleum (blank) and not pickled as a function of time of degradation

\begin{tabular}{lccc}
\hline \multirow{2}{*}{ Sample } & & Analyzed parameter & Sku \\
\hline & Peak-peak & SsK & 2.2 \\
\hline Blank & $67.41 \mathrm{c}^{\mathrm{a}}$ & -0.12 & 3.91 \\
$6 \mathrm{~h}$ before Clark solution (layer sulfide) & $553.36 \mathrm{ab}$ & 0.23 & 6.72 \\
$6 \mathrm{~h}$ after Clark solution & $230.64 \mathrm{c}$ & 0.49 & 2.59 \\
$12 \mathrm{~h}$ before Clark solution (layer sulfide) & $518.46 \mathrm{~b}$ & 0.06 & 5.16 \\
$12 \mathrm{~h}$ after Clark solution & $209.35 \mathrm{c}$ & 0.87 & 3.08 \\
$24 \mathrm{~h}$ before Clark solution (layer sulfide) & $1037.99 \mathrm{ab}$ & -0.07 & 3.08 \\
$24 \mathrm{~h}$ after Clark solution & $1037.99 \mathrm{bc}$ & -0.07 & 2.77 \\
$36 \mathrm{~h}$ before Clark solution (layer sulfide) & $534.84 \mathrm{ab}$ & -0.07 & 3.48 \\
$36 \mathrm{~h}$ after Clark solution & $520.32 \mathrm{~b}$ & -0.24 & 3.39 \\
$48 \mathrm{~h}$ before Clark solution (layer sulfide) & $1110.76 \mathrm{ab}$ & -0.10 & 4.11 \\
$48 \mathrm{~h}$ after Clark solution & $812.88 \mathrm{a}$ & -0.31 & 3.06 \\
$72 \mathrm{~h}$ before Clark solution (layer sulfide) & $662.15 \mathrm{a}$ & -0.13 & 3.81 \\
$72 \mathrm{~h}$ after Clark solution & $321.16 \mathrm{bc}$ & -0.43 & \\
\hline
\end{tabular}

${ }^{a}$ Average values followed by equal letters do not differ statistically by the Tukey test $(p<0.05)$. SsK: surface asymmetry parameter; Sku: surface kurtosis. 
After $\mathrm{t}=24 \mathrm{~h}$, it is noticed the absence of the peak at $660 \mathrm{~cm}^{-1}$, referring to the presence of $\mathrm{Fe}_{3} \mathrm{O}_{4}$. The absence of $\mathrm{Fe}_{3} \mathrm{O}_{4}$ indicates that with the increasing of exposure time, equation 9 is favored, leading to the majority formation of hematite $\left(\alpha-\mathrm{Fe}_{2} \mathrm{O}_{3}\right)$ on the surface of the specimens.

\section{Conclusions}

One of the main objectives of research in petroleum chemistry is to correlate the composition of petroleum with its physical and chemical characteristics and to study the impact of these characteristics on petroleum production and refining. We have demonstrated the great potential of the association between physicochemical, microscopic and spectroscopic techniques in characterizing the corrosive behavior of an acidic crude oil sample on the AISI 1020 steel surfaces. Here, we show that the thermal degradation of heavy oil favored the decarboxylation of NAs since it was observed a reduction of $37 \%$ in TAN and $8 \%$ in total $\mathrm{S}$ content at $320^{\circ} \mathrm{C}$ and $72 \mathrm{~h}$. Moreover, weight loss analysis has shown that the corrosion rate of AISI 1020 steel becomes stable from $t=24 \mathrm{~h}$ of oil exposure. The stability of corrosion rate could be due to the deposition of a passivation film on the steel surface starting at a time interval of $6 \mathrm{~h}$. The association of the LM, SEM/EDX, and AFM allowed a detailed analysis of the steel surface and revealed that the corrosion process is governed by the presence of two layers, a more external being composed of $\mathrm{FeS}$ and another by iron oxides and oxyhydroxides (hematite, goethite, and magnetite).

\section{Acknowledgments}

The authors are grateful to CENPES/PETROBRAS for financing the research (process No. 2014/00254-5) and the National Council for Scientific and Technological Development (Conselho Nacional de Desenvolvimento Científico e Tecnológico, $\mathrm{CNPq}$ ) for the fellowships. The authors also thank the Núcleo de Competências em Química do Petróleo (UFES) for the corrosion assays and LabPetro for the chemical characterization of the oil.

\section{References}

1. Derungs, W. A.; Corrosion 1956, 12, 41.

2. Moura, L. B.; Guimarães, R. F.; Abreu, H. F. G.; Miranda, H. C.; Tavares, S. S. M.; Mater. Res. 2012, 15, 277.

3. Babaian-Kibala, E.; Craig, H. L.; Rusk, G. L.; Blanchard, K. V.; Rose, T. J.; Uehlein, B. L.; Quinter, R. C.; Summers, M. A.; Mater. Perform. 1993, 32, 50.
4. Restrepo, C. E.; Simonoff, J. S.; Zimmerman, R.; Int. J. Crit. Infr. Prot. 2009, 2, 38.

5. Gruber, L. D. A.; Quim. Nova 2012, 35, 1423.

6. Qian, K.; Robbins, W. K.; Hughey, C. A.; Cooper, H. J.; Rodgers, R. P.; Marshall, A. G.; Energy Fuels 2001, 11, 1505.

7. Tozzi, F. C.; Sad, C. M. S.; Bassane, J. F. P.; dos Santos, F. D.; Silva, M.; Filgueiras, P. R.; Dias, H. P.; Romão, W.; de Castro, E. V. R.; Lacerda Jr., V.; Fuel 2015, 159, 607.

8. Laredo, G. C.; López, C. R.; Àlvarez, R. E.; Cano, J. L.; Fuel 2004, 83, 1689.

9. Hsu, C. S.; Dechert, G. J.; Robbins, W. K.; Fukuda, E. K.; Energy Fuels 2000, 14, 217.

10. Slavcheva, E.; Shone, B.; Turnbull, A.; Br. Corros. J. 1999, 34 , 125.

11. Yang, B.; Xu, C.; Zhao, S.; Hsu, C. S.; Chung, K. H.; Shi, Q.; Sci. China Chem. 2013, 56, 848.

12. Sixian, R.; Yu, Z.; Ziwei, P.; Yuwan, C.; Xuedong, C.; Mater. Corros. 2014, 65, 619.

13. ASTM International; ASTM G31-72: Standard Practice for Laboratory Immersion Corrosion Testing of Metals; ASTM International: West Conshohocken, PA, 1999.

14. Deyab, M. A.; Abo Dief, H. A.; Eissa, E. A.; Taman, A. R.; Electrochim. Acta 2007, 52, 8105.

15. Dias, H. P.; Pereira, T. M. C.; Vanini, G.; Dixini, P. V. M.; Celante, V. G.; de Castro, E. V. R.; Vaz, B. G.; Gomes, A. O.; Aquije, G. M. F. V.; Romão, W.; Fuel 2014, 126, 85.

16. Dias, H. P.; Dixini, P. V.; Almeida, L. C. P.; Vanini, G.; Castro, E. V. R.; Aquije, G. M. F. V.; Gomes, A. O.; Moura, R. R.; Lacerda Jr., V.; Vaz, B. G.; Romão, W.; Fuel 2015, 139, 328.

17. ASTM International; ASTM D4377: Standard Test Method for Karl Fischer in Crude Oil; ASTM International: West Conshohocken, PA, 2006.

18. International Organization for Standardization (ISO); ISO 12185:1996: Crude Petroleum and Petroleum Products Determination of Density - Oscillating U-Tube Method; ISO: Geneva, Switzerland, 1996.

19. ASTM International; ASTM D1250: Standard Guide for Petroleum Measurement Tables; ASTM International: West Conshohocken, PA, 2008.

20. ASTM International; ASTM D664: Standard Test Method for Acid Number of Petroleum Products by Potentiometric Titration; ASTM International: West Conshohocken, PA, 2011.

21. ASTM International; ASTM D4294: Standard Test Method for Sulfur in Petroleum and Petroleum Products by Energy Dispersive X-Ray Fluorescence Spectrometry; ASTM International: West Conshohocken, PA, 2010.

22. Fornós, J. J.; Gómez-Pujol, L.; Cifre, J.; Hierro, F.; Acta Carsologica 2011, 40, 275.

23. Batina, N.; Manzano-Martinez, J. C.; Andersen, S. I.; LiraGaleana, C.; Energy Fuels 2003, 17, 532. 
24. Colati, K. A. P.; Dalmaschio, G. P.; Castro, E. V. R.; Gomes, A. O.; Vaz, B. G.; Romão, W.; Fuel 2013, 108, 647.

25. Freitas, S.; Malacarne, M. M.; Romão, W.; Dalmaschio, G. P.; Castro, E. V. R.; Celante, V. G.; Freitas, M. B. J. G.; Fuel 2013, 104, 656.

26. Barros, E. V.; Dias, H. P.; Gomes, A. O.; Rodrigues, R. T.; Moura, R. R.; Sad, C. M. S.; Freitas, J. C. C.; Cunha Neto, A.; Aquije, G. M. F. V.; Romão, W.; J. Pet. Sci. Eng. 2017, 154, 194.

27. Smith, D. F.; Rodgers, R. P.; Rahimi, P.; Teclemariam, A.; Marshall, A. G.; Energy Fuels 2009, 23, 314.

28. Yépez, O.; Fuel 2005, 84, 97.

29. Rios, E. C.; Zimer, A. M.; Mendes, P. C. D.; Freitas, M. B. J.; Castro, E. V. R.; Mascaro, L. H.; Pereira, E. C.; Fuel 2015, 150, 325.

30. Alvisi, P. P.; Lins, V. F. C.; Eng. Failure Anal. 2011, 18, 1403.
31. Zeinalov, E. B.; Abbasov, V. M.; Alieva, L. I.; Pet. Chem. 2009, 49, 203.

32. Deyab, M. A.; Corros. Sci. 2007, 49, 2315.

33. Jeyaprabha, C.; Sathiyanarayanan, S.; Venkatachari, G.; Appl. Surf. Sci. 2005, 246, 108.

34. Huang, B. S.; Yin, W. F.; Sang, D. H.; Jiang, Z. Y.; Appl. Surf. Sci. 2012, 259, 664.

35. Butt, H. J.; Cappella, B.; Kappl, M.; Surf. Sci. Rep. 2005, 59, 1.

36. Faria, D. L. A.; Silva, S. V.; Oliveira, M. T.; J. Raman Spectrosc. 1997, 28, 873.

37. Avril, C.; Malavergner, V.; Caracas, R.; Zanda, B.; Reynard, B.; Charon, E.; Bobocioiu, E.; Brunet, F.; Borensztajn, S.; Pont, S.; Tarrida, M.; Guyot, F.; Meteorit. Planet. Sci. 2013, 48, 1415.

Submitted: November 29, 2017

Published online: March 8, 2018 